\title{
HAEMOPTYSIS- AETIOPATHOLOGICAL, RADIOLOGICAL PROFILE AND ITS OUTCOME, OUR EXPERIENCE
}

\author{
Manish Shankar1, Kalyan Kumar Saha², Praveen Kumar³, Mukesh Kumar Tiwari4, Samir Kumar ${ }^{5}$
}

${ }_{1}^{1}$ Associate Professor \& HOD, Department of TB and Chest, IGIMS, Patna, Bihar.

${ }^{2}$ Senior Resident, Department of General Medicine, IGIMS, Patna, Bihar.

${ }_{3}^{3}$ Associate Professor, Department of General Medicine, IGIMS, Patna, Bihar.

${ }^{4}$ Senior Resident, Department of TB and Chest, IGIMS, Patna, Bihar.

${ }^{5}$ Senior Resident, Department of TB and Chest, IGIMS, Patna, Bihar.

\section{BACKGROUND}

\section{ABSTRACT}

Haemoptysis is a common complaint in many patients attending chest department. It can be due to a number of aetiologies, having different pathogenesis, radiological presentation and requires optimum management. This study is carried out to evaluate the aetiology, pathogenesis, its radiological profile and outcome in patients of haemoptysis in patients attending TB and Chest Department of Indira Gandhi Institute of Medical Sciences, Patna, Bihar, India.

\section{MATERIALS AND METHODS}

A hospital-based retrospective observational study was done in TB and Chest Department of Indira Gandhi Institute of Medical Sciences, Patna, Bihar, India from December 2016 to February 2018. A total of 254 patient's records were analysed. Their clinical details, radiological investigations, bronchoscopic findings and outcome were recorded as per a pre-designed proforma and analysed.

\section{RESULTS}

A total of 254 patients of haemoptysis were included in our study. Of these, $61.41 \%$ were males and $38.58 \%$ were females. Most of the patients fall into age group of 31 - 45 years, i.e. 29.13\%. Most common cause of haemoptysis was tuberculosis, both active and its sequel (32.28\%) followed by lung malignancy in $14.56 \%$. Non-small cell lung carcinoma (NSCLC) was the common entity among lung malignancy, i.e. 78.37\%. Lung carcinoma was more common among active smokers (23.45\%). Most of the cases were having mild haemoptysis (34.25\%) and were managed conservatively successfully (92.12\%). Chest x-ray was done in $100 \%$ cases, computed tomography scan (CT scan) in $79.13 \%$ and bronchoscopy was done in $59.44 \%$ cases to identify the aetiology of haemoptysis. 9.44\% patients died despite best available management in our institute.

\section{CONCLUSION}

Tuberculosis either active or post-TB sequel is found to be the most common aetiology of haemoptysis in this part of the world followed by lung malignancy and bronchiectasis. Most of the cases can be managed conservatively and outcome of conservative management remains better in controlling active bleed.

\section{KEYWORDS}

Haemoptysis, Tuberculosis, Patna.

HOW TO CITE THIS ARTICLE: Shankar M, Saha KK, Kumar P, et al. Haemoptysis- aetiopathological, radiological profile and its outcome, our experience. J. Evolution Med. Dent. Sci. 2018;7(17):2078-2083, DOI: 10.14260/jemds/2018/466

\section{BACKGROUND}

Coughing out blood, either frank or mixed with sputum is called haemoptysis. Bleeding can arise from any part of tracheobronchial tree or may be due to diseases of the pulmonary parenchyma or pulmonary vascular system. Haemoptysis can arise either due to bleeding from bronchial arteries and/or pulmonary arteries. Bronchial vessels are the source in majority of cases, while pulmonary artery being the source in $<10 \%$ of the cases. ${ }^{1}$ It can be scanty, mild, moderate, severe, massive or life threatening. It is a manifestation of several diseases involving respiratory

'Financial or Other Competing Interest': None.

Submission 29-03-2018, Peer Review 10-04-2018,

Acceptance 13-04-2018, Published 23-04-2018.

Corresponding Author:

Manish Shankar

Associate Professor \& HOD,

Department of TB and Chest,

IGIMS, Patna-800014, Bihar.

E-mail:drmnsh@gmail.com

DOI: $10.14260 /$ jemds $/ 2018 / 466$

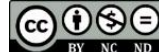

system with tuberculosis leading as a principal cause in this region. Whatever the cause may be, it is a cause of concern for the patient and requires full diagnostic workup.

Pulmonary tuberculosis, lung malignancy and bronchiectasis appear to be the principal cause of haemoptysis in this region. Pulmonary tuberculosis is an important cause of haemoptysis in developing countries, $2-5$ whereas in developed countries bronchiectasis, lung cancer and bronchitis are the main causes.6-8

Any case of haemoptysis should be fully investigated with full clinical detail, smoking history, sputum examinations, chest x-ray or computed tomography (CT scan) thorax and if required bronchoscopy should also be considered. Even after a detailed investigation, sometimes no cause can be found in $20 \%-30 \%$ of patients. ${ }^{9,10}$

Haemoptysis is generally managed conservatively along with treatment of the cause; however, it may need bronchial artery embolisation or surgical intervention if not controlled effectively with conservative measures. 


\section{Aims and Objectives}

To study the aetiology, pathogenesis, radiological profile and outcome in patients of haemoptysis, in patients attending TB and Chest Department of Indira Gandhi Institute of Medical Sciences, Patna, Bihar, India.

\section{MATERIALS AND METHODS}

This was a hospital-based retrospective study done in the patients attending TB and Chest Department in Indira Gandhi Institute of Medical Sciences, Patna, Bihar with the complaint of haemoptysis from December 2016 to February 2018. Patients with haematemesis, oral mucosal bleed and otorhinolaryngological source of bleeding were excluded from the study. A total of 254 patients with true haemoptysis were included in the study. Their complete history including any blood dyscrasia, age, sex, clinical profile, smoking history, severity of haemoptysis and its frequency, drug history including use of anticoagulants, investigations done, radiological picture, 2D echocardiography reports to rule out any cardiac cause of haemoptysis, definitive diagnosis and outcome were recorded in a predesigned proforma from the records of the department and analysed.

\section{Inclusion Criteria}

Patients with true haemoptysis attending TB and Chest Department of Indira Gandhi Institute of Medical Sciences, Patna, Bihar.

\section{Exclusion Criteria}

i) Patients less than 15 years of age.

ii) Bleeding from non-respiratory source such as haematemesis, oral mucosal bleed and otorhinolaryngological bleeding.

A detailed clinical history and physical examinations were done of each patient. Smoking history present or past were recorded. Severity of haemoptysis was assessed based on amount of blood loss. Severity of haemoptysis was categorised as mild $(<30 \mathrm{~mL})$, moderate $(31-100 \mathrm{~mL})$, severe $(101-600 \mathrm{~mL})$, massive haemoptysis $(>600 \mathrm{~mL})$ and life threatening for haemoptysis with haemodynamic and respiratory compromise. A routine haematological examinations and coagulation profile were done. Sputum for acid fast bacilli, sputum for gene xpert, sputum culture/sensitivity and sputum fungal culture were done where indicated. Chest x-ray was done of every patient. Computed tomography scan (CT scan) thorax was done where indicated. Fiberoptic bronchoscopy was done in selected patients in whom definitive diagnosis and source of bleeding was not established. Adequate histopathological specimen was also collected during bronchoscopy. All the patients were initially managed conservatively with antitussives, bed rest along with treatment of the cause with significant success. Only patients with uncontrolled haemoptysis were subjected for operative procedures such as lobectomy/segmentectomy where indicated. Some patients who needed bronchial/pulmonary artery embolisation were referred to other centres due to lack of this facility in our institute.

\section{Statistical Analysis}

Data were analysed using statistical software Epi Info. Descriptive statistics like mean and percentages were used for the analysis.

\section{RESULTS}

254 patients attended the TB and Chest department for control of haemoptysis, of which $156(61.41 \%)$ were males and $98(38.58 \%)$ were females (Graph 1).

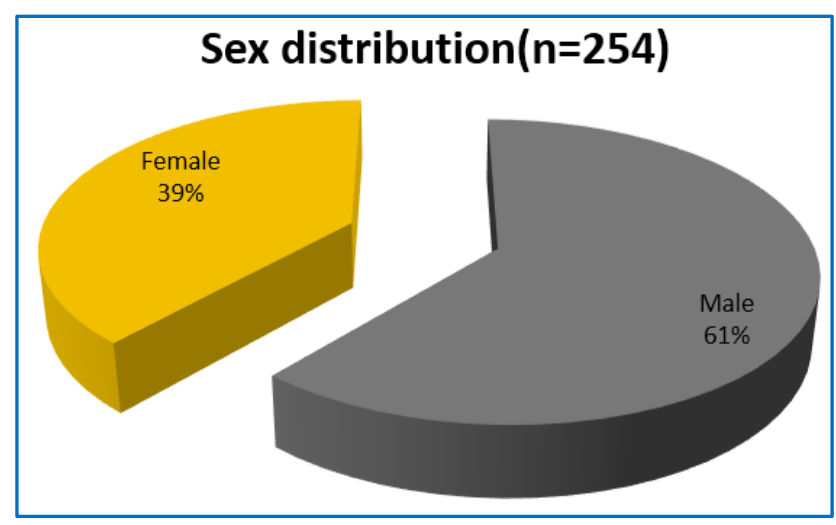

Graph 1. Sex Distribution

148 patients (58.26\%) were having first episode of haemoptysis, whereas 96 (37.79\%) were having previous episodes. In 10 patients, no data about haemoptysis history was recorded. Most of the patients (29.13\%) belonged to age group 31 - 45 years (Graph 2).

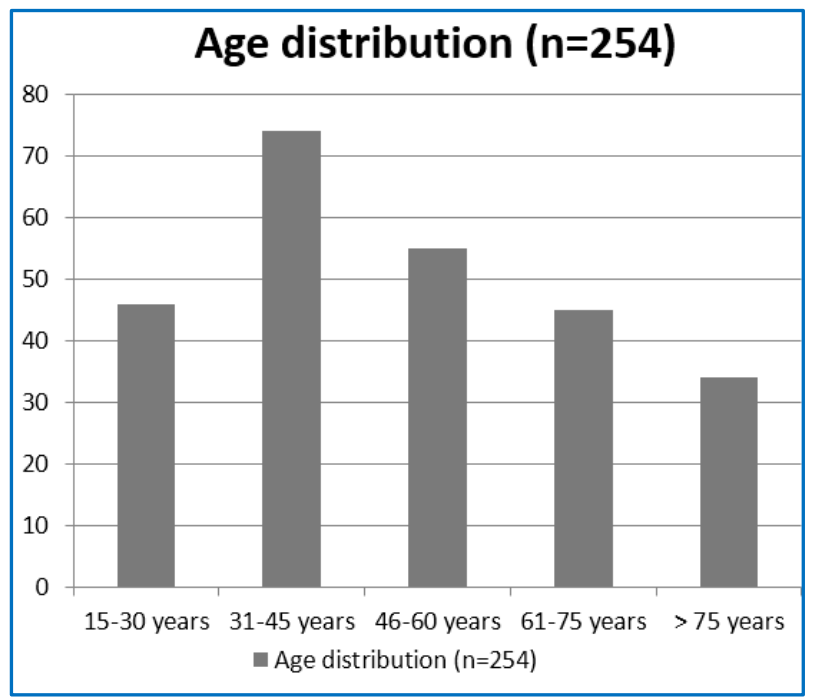

Graph 2. Age Distribution

Most of the patients were diagnosed of having present or past tuberculosis with $12.99 \%$ having active tuberculosis. Post tuberculosis sequel were the commonest diagnosis, i.e. in $19.29 \%$. Lung cancer was the cause of haemoptysis in $14.56 \%$, whereas bronchiectasis was the reason in $11.02 \%$. Pneumonia was the cause in $8.26 \%$. 27 patients $(10.62 \%)$ remain undiagnosed (Graph 3). 


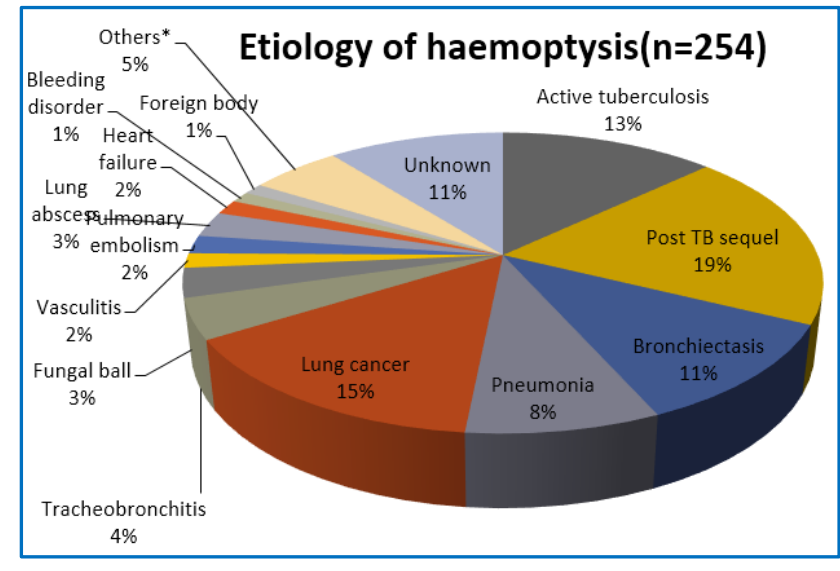

Graph 3. Aetiology of haemoptysis

*Post lobectomy syndrome (2), Benign endobronchial mass (2), Silicosis (2), Chronic obstructive pulmonary disease (2), Mitral stenosis (2), Congenital pulmonary vascular malformation (2), Arteriovenous fistula (1), Congenital lung malformation (1).

$31.88 \%$ patients were current smokers with lung cancer being the most common diagnosis in them, i.e. $23.45 \%$. $26.77 \%$ were former smokers who left smoking 1 year back with post tuberculosis sequel being the most common diagnosis in that group, i.e. $33.82 \%$. Most of the patients were non-smokers $41.33 \%$ with pulmonary tuberculosis sequel being the most common diagnosis in that group, i.e. in $16.19 \%$ (Table 1).

\begin{tabular}{|c|c|c|}
\hline Smoker & $\begin{array}{c}\text { Number }(n=81) \\
31.88 \%\end{array}$ & Percentage (\%) \\
\hline \begin{tabular}{|c|} 
Pulmonary \\
tuberculosis \\
Lung carcinoma \\
Pulmonary \\
tuberculosis sequel \\
Bronchiectasis \\
\end{tabular} & $\begin{array}{c}14 \\
19 \\
9 \\
8\end{array}$ & $\begin{array}{c}17.28 \% \\
23.45 \% \\
11.11 \% \\
9.87 \%\end{array}$ \\
\hline Former Smoker & $\begin{array}{c}\text { Number }(n=68) \\
26.77 \% \\
\end{array}$ & Percentage (\%) \\
\hline \begin{tabular}{|c|} 
Pulmonary \\
tuberculosis sequel \\
Lung carcinoma \\
Pulmonary \\
tuberculosis \\
Bronchiectasis
\end{tabular} & $\begin{array}{c}23 \\
12 \\
10 \\
7\end{array}$ & $\begin{array}{l}33.82 \% \\
17.64 \% \\
14.70 \% \\
10.29 \%\end{array}$ \\
\hline Non-smoker & $\begin{array}{c}\text { Number }(n=105) \\
41.33 \% \\
\end{array}$ & Percentage (\%) \\
\hline \begin{tabular}{|c|} 
Pulmonary \\
tuberculosis sequel \\
Bronchiectasis \\
Pulmonary \\
tuberculosis \\
Lung carcinoma
\end{tabular} & $\begin{array}{c}17 \\
13 \\
9 \\
6\end{array}$ & $\begin{array}{c}16.19 \% \\
12.38 \% \\
8.57 \% \\
5.71 \%\end{array}$ \\
\hline
\end{tabular}

37 patients were finally diagnosed with lung cancer, of which $78.37 \%$ were non-small cell lung carcinoma (NSCLC) and $21.62 \%$ were of small cell lung carcinoma (SCLC). Adenocarcinoma was the most common lung cancer identified histopathologically (51.72\%) among non-small cell lung carcinoma. Around $17.24 \%$ cases of carcinoma were not categorised histologically and were marked as poorly differentiated carcinoma (Table 2).

\begin{tabular}{|c|c|c|}
\hline $\begin{array}{c}\text { Non-small cell lung } \\
\text { carcinoma subtypes } \\
\mathrm{n}=29(78.37 \%)\end{array}$ & $\begin{array}{c}\text { Squamous cell } \\
\text { carcinoma } \\
\text { Adenocarcinoma }\end{array}$ & $\begin{array}{c}8(27.58 \%) \\
\text { Large cell carcinoma }\end{array}$ \\
$\begin{array}{c}\text { Poorly differentiated } \\
\text { carcinoma }\end{array}$ & $5(1.41 .72 \%)$ \\
\hline $\begin{array}{c}\text { Small cell lung } \\
\text { carcinoma } \\
\mathrm{n}=8(21.62 \%)\end{array}$ & $8(100 \%)$ \\
\hline \multicolumn{2}{|c|}{ Table 2. Distribution of Lung Cancer (n= 37) } \\
as a cause of Haemoptysis
\end{tabular}

Malignancy was most commonly diagnosed in increasing age, i.e. in > 61 years' age group. Patients presented with varying severity of haemoptysis, but most of the patients (34.25\%) were having mild (<30 mL) bleeding. 18.89\% patients were having moderate $(31-100 \mathrm{~mL})$ bleed. Severe $(101-600 \mathrm{~mL})$ and massive $(>600 \mathrm{~mL})$ bleeding were found in only $8.26 \%$ and $5.11 \%$ respectively. In around 82 patients (32.28\%), severity of bleeding were not recorded. Among mild haemoptysis group, post tuberculosis sequel were the most common aetiology, i.e. $24.13 \%$. Active pulmonary tuberculosis was the main cause of moderate bleeding in $20.83 \%$. Severe, massive and life-threatening bleeding was most commonly associated with lung carcinoma in $61.90 \%$, $53.84 \%$ and $33.33 \%$ respectively (Table 3 ).

\begin{tabular}{|c|c|c|c|}
\hline $\begin{array}{l}\text { Severity and } \\
\text { Amount of } \\
\text { Haemoptysis } \\
\text { (n=254) \% }\end{array}$ & $\begin{array}{l}\text { Common } \\
\text { Aetiology }\end{array}$ & Nos. & $\%$ \\
\hline $\begin{array}{c}\text { Mild }(<30 \mathrm{~mL}) \\
\text { (n=87) } \\
34.25 \%\end{array}$ & \begin{tabular}{|c|} 
Pulmonary tuberculosis \\
sequel \\
Pulmonary tuberculosis \\
Bronchiectasis \\
Lung carcinoma \\
Pneumonia \\
Others \\
\end{tabular} & $\begin{array}{c}21 \\
17 \\
11 \\
9 \\
7 \\
22\end{array}$ & \begin{tabular}{|c|}
$24.13 \%$ \\
$19.54 \%$ \\
$12.64 \%$ \\
$10.34 \%$ \\
$8.04 \%$ \\
$25.28 \%$
\end{tabular} \\
\hline $\begin{array}{c}\text { Moderate } \\
(31-100 \mathrm{~mL}) \\
(\mathrm{n}=48) 18.89 \%\end{array}$ & $\begin{array}{c}\text { Pulmonary tuberculosis } \\
\text { Bronchiectasis } \\
\text { Pulmonary tuberculosis } \\
\text { sequel } \\
\text { Lung carcinoma } \\
\text { Others } \\
\end{array}$ & $\begin{array}{c}10 \\
9 \\
8 \\
7 \\
14\end{array}$ & $\begin{array}{l}20.83 \% \\
18.75 \% \\
16.66 \% \\
14.58 \% \\
29.16 \%\end{array}$ \\
\hline $\begin{array}{c}\text { Severe }(101-600 \\
\text { mL) } \\
(n=21) 8.26 \%\end{array}$ & \begin{tabular}{|c|} 
Lung carcinoma \\
Pulmonary tuberculosis \\
sequel \\
Bronchiectasis \\
\end{tabular} & $\begin{array}{c}13 \\
5 \\
3\end{array}$ & $\begin{array}{l}61.90 \% \\
23.80 \% \\
14.28 \%\end{array}$ \\
\hline $\begin{array}{c}\text { Massive }(>600 \mathrm{~mL}) \\
(\mathrm{n}=13) 5.11 \%\end{array}$ & \begin{tabular}{|c|} 
Lung carcinoma \\
Bronchiectasis \\
Pulmonary tuberculosis \\
sequel \\
\end{tabular} & $\begin{array}{l}7 \\
4 \\
2\end{array}$ & \begin{tabular}{|l|}
$53.84 \%$ \\
$30.76 \%$ \\
$15.38 \%$
\end{tabular} \\
\hline $\begin{array}{l}\text { Life Threatening } \\
\quad(n=3) 1.18 \%\end{array}$ & $\begin{array}{c}\text { Lung carcinoma } \\
\text { Congenital pulmonary } \\
\text { vascular malformation } \\
\text { Bronchiectasis }\end{array}$ & $\begin{array}{l}1 \\
1 \\
1\end{array}$ & $\begin{array}{l}33.33 \% \\
33.33 \% \\
33.33 \%\end{array}$ \\
\hline $\begin{array}{c}\text { Severity Unknown } \\
(\mathrm{n}=82) 32.28 \%\end{array}$ & \begin{tabular}{|c|} 
Pneumonia \\
Pulmonary tuberculosis \\
sequel \\
Tracheobronchitis \\
Pulmonary tuberculosis \\
Others
\end{tabular} & $\begin{array}{c}14 \\
13 \\
11 \\
6 \\
38\end{array}$ & \begin{tabular}{|c|}
$17.07 \%$ \\
$15.85 \%$ \\
$13.41 \%$ \\
$7.31 \%$ \\
$46.34 \%$
\end{tabular} \\
\hline
\end{tabular}


A number of methods were used for diagnosing the cause of haemoptysis. Chest x-ray was done in almost all patients $(100 \%)$ with $55.11 \%$ positive outcome. 39 chest $x$-rays were apparently normal. Among them tracheobronchitis, bronchiectasis and pulmonary thromboembolism were the final diagnoses on further workup. Fibrocavitary disease, infiltration and mass/consolidation was the most common findings on chest x-ray, which was later confirmed by computed tomography (CT) scan thorax. In patients where diagnosis remain doubtful were subjected for computed tomography scan (CT scan) thorax, i.e. in $79.13 \%$ with $80.59 \%$ positive outcome. Most of the CT scan showed fibrocavitary, bronchiectatic or mass/collapse consolidation and ground glass opacity. Tracheobronchitis was diagnosed in 9 patients having normal CT scan. Bronchoscopy was done where indicated in $59.44 \%$ with $54.96 \%$ positive outcome. Fiberoptic bronchoscopy was successful in locating the source of bleeding in 46 (30.46\%) patients, while in 39 (25.82\%) no intrabronchial lesion was identified. Some radiologically unidentified lung lesion required computed tomography (CT)/ultrasound (USG) guided fine needle aspiration cytology (FNAC)/tru-cut biopsy in $10.62 \%$ with $59.25 \%$ positive outcome. Sputum for acid fast bacilli (AFB) smear/gene xpert was done to diagnose activity in suspected cases of tuberculosis in around $70.47 \%$ with $18.43 \%$ cases were successfully diagnosed with tuberculosis. Sputum for malignant cytology is a simple, non-invasive and economical diagnostic test for diagnosing lung malignancy. It was done in $15.74 \%$ of patients with suspected malignancy with $12.5 \%$ cases showing malignant cells in sputum (Graph 4).

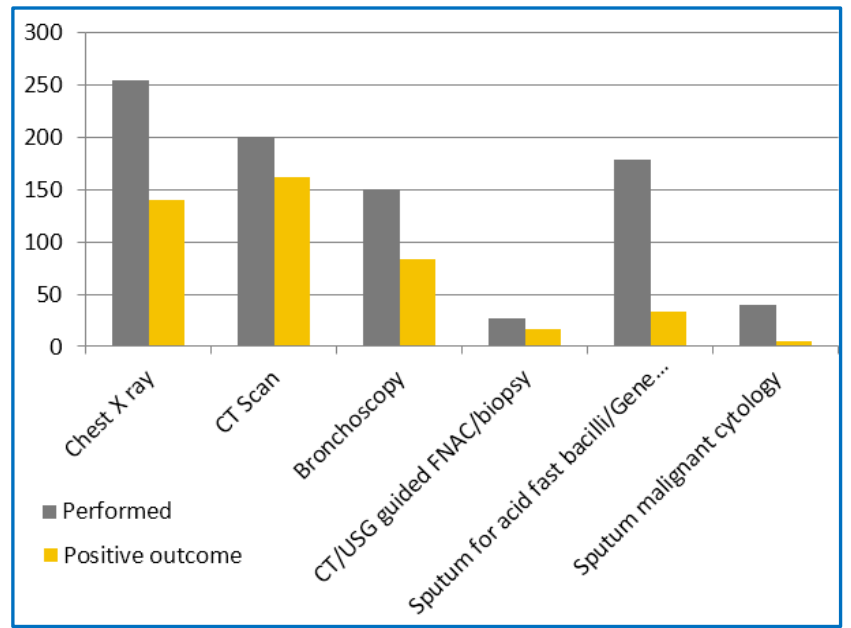

Graph 4. Diagnostic Tests and its Outcome

Most of the cases were managed conservatively (in 92.12\%) with medical management, antitussives, haemostatic agents like tranexamic acids along with treatment of the aetiology. Conservative management was used most commonly in pulmonary tuberculosis and its sequel $14.10 \%$ and $20.08 \%$ respectively. Around $13.24 \%$ of lung cancer patients were also managed conservatively. 170 $(66.92 \%)$ patients were managed on an outpatient basis, 63 (24.8\%) patients were admitted for haemoptysis control and $21(8.26 \%)$ patients required ICU care. Surgical treatment was used when medical management failed and was used most commonly in fungal ball (33.33\%), in lung abscess
(26.66\%) and in some cases of focal bronchiectasis restricted to some lobe or segment, i.e. in $13.33 \%$ in the form of lobectomy/segmentectomy. Flexible fiberoptic bronchoscopy was used to control bleeding (in 3.14\%) in cases of foreign body which was also removed subsequently and in 2 cases of lung cancer with cold saline lavage and local instillation of vasoconstrictor, both cases relapsed with haemoptysis few days after the procedure. Rigid bronchoscopy was not done in any patient because of unavailability of the instrument. Two cases of lung cancer having uncontrolled bleeding were managed with radiation therapy. Since facility for bronchial artery embolisation is not available in our institute $16(6.29 \%)$ patients were referred to another centre for this procedure. Conservative/medical management was highly successful in managing haemoptysis in almost $92.3 \%$. Surgical treatment was used in 15 patients with $86.66 \%$ success rate. Bronchoscopy was successful in controlling bleeding in 5 out of 8 patients. Radiation therapy was effective in controlling haemoptysis in 1 out of 2 patients (Table 4).

\begin{tabular}{|c|c|c|c|}
\hline $\begin{array}{c}\text { Treatment } \\
\text { Offered }\end{array}$ & $\begin{array}{c}\text { Number } \\
(\%)\end{array}$ & Main Disease & $\begin{array}{c}\text { Number } \\
(\%)\end{array}$ \\
\hline $\begin{array}{c}\text { Conservative/ } \\
\text { Medical } \\
\text { Treatment }\end{array}$ & $\begin{array}{c}234 \\
(92.12 \%)\end{array}$ & \begin{tabular}{|c} 
Pulmonary \\
tuberculosis \\
Pulmonary \\
tuberculosis sequel \\
Bronchiectasis \\
Lung cancer
\end{tabular} & \begin{tabular}{|c}
33 \\
$(14.1 \%)$ \\
47 \\
$(20.08 \%)$ \\
23 \\
$(9.82 \%)$ \\
31 \\
$(13.24 \%)$
\end{tabular} \\
\hline $\begin{array}{l}\text { Surgical } \\
\text { Treatment }\end{array}$ & $15(5.9 \%)$ & $\begin{array}{c}\text { Fungal ball } \\
\text { Lung abscess } \\
\text { Bronchiectasis }\end{array}$ & $\begin{array}{c}5 \\
(33.33 \%) \\
4 \\
(26.66 \%) \\
2 \\
(13.33 \%)\end{array}$ \\
\hline $\begin{array}{c}\text { Bronchoscopic } \\
\text { Control of } \\
\text { Bleeding }\end{array}$ & $8(3.14 \%)$ & $\begin{array}{l}\text { Foreign body } \\
\text { Lung cancer }\end{array}$ & $\begin{array}{c}3(37.5 \%) \\
2(25 \%)\end{array}$ \\
\hline $\begin{array}{l}\text { Radiation } \\
\text { Therapy }\end{array}$ & $2(0.78 \%)$ & Lung cancer & $2(100 \%)$ \\
\hline
\end{tabular}

$7.69 \%$ patients died who were managed conservatively, $13.33 \%$ died who were managed surgically, $37.5 \%$ in patients where bronchoscopy was done to control bleeding and 1 patient $(50 \%)$ died out of 2 where radiotherapy was given. The main diagnosis in patients who died was of lung carcinoma, bronchiectasis and tuberculosis. Data about outcome of bronchial artery embolisation done in patients were not available in the record, as patients were referred to another centre for this procedure. Most of the patient referred were of post tuberculosis sequel, bronchiectasis, lung cancer and pulmonary vascular malformation (Graph 5). 


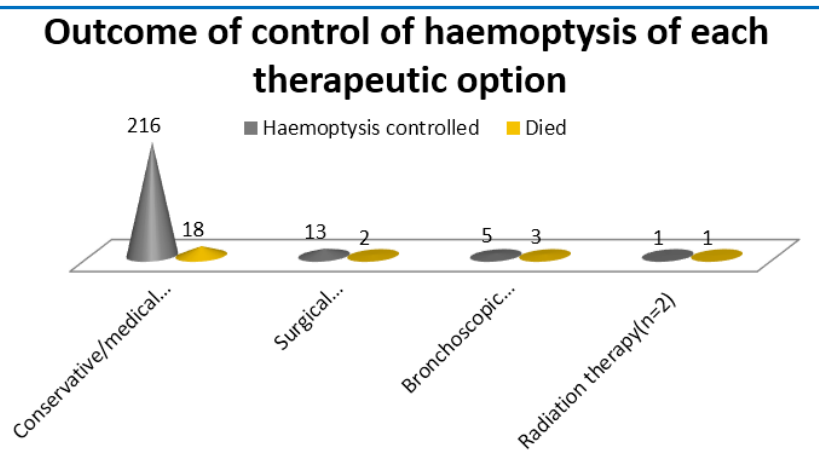

Graph 5. Outcome of Control of Haemoptysis of each Therapeutic Option

\section{DISCUSSION}

A total of 254 patients with haemoptysis were included in the study with males (61.41\%) outnumbering females. Majority of patients were of age group 31 - 45 years (29.13\%), probably due to increased incidence of tuberculosis in this age group.

There were multiple causes of haemoptysis in patients attending $\mathrm{TB}$ and chest department of this institute but tuberculosis, both active and its sequel remain the leading cause of haemoptysis in this region. Initial study by Rao from India in 1960 declared tuberculosis to be the leading cause of haemoptysis. ${ }^{10}$ The scenario is still the same in our country. Our study also showed the same result with tuberculosis and it remains the most common cause of haemoptysis with $32.28 \%$ occurrence (both active and post-TB sequel) as in other recently reported studies from India.10-13 Lung cancer was the second most common cause of haemoptysis $(14.56 \%)$ in our study. Incidence of malignancy regarding epidemiology of haemoptysis in developed countries ranges from $5 \%$ to $44 \% .14,15-18$ Indian studies do not report such high incidence of lung malignancy as cause of haemoptysis $(0 \%$ $6.6 \%)^{10-12,19-21}$ In the present study malignancy was the reason for active haemoptysis in $14.56 \%$ patients, which was slightly higher than other studies probably due to either increased lung cancer incidence in this reason or consolidation of cases to this centre as this is a tertiary care institute. Non-small cell lung carcinoma was the predominant type of lung malignancy (78.37\%). Among malignancies in most series, squamous cell carcinoma is the main responsible for haemoptysis. ${ }^{6}$ However, adenocarcinoma is the most common histological diagnosis (51.72\%) among non-small cell lung cancer (NSCLC) in our study followed by squamous cell carcinoma $(27.58 \%)$. The reason behind increased adenocarcinoma incidence may be the increased prevalence of adenocarcinoma as compared to squamous cell carcinoma these days. ${ }^{22,23}$ No histological diagnosis could be made in $17.24 \%$ of carcinoma cases and was identified as poorly differentiated carcinoma. Malignancy was more common in advanced age group of above 60 years in accordance with reviewed literature. 4 Man surpassing women in cases of malignancy may be due to increased smoking habits among them. Smoking was the predominant cause of haemoptysis due to occurrence of malignancy (23.45\%) as compared to former smoker, where post tuberculosis sequel was the predominant cause $(33.82 \%)$. Lung malignancy occurrence gradually waned from smoker to former smoker $(17.64 \%)$ to non-smoker (5.71\%). Pulmonary tuberculosis also were more common in smokers and former smokers than non- smokers. Some recent studies actually have shown an association between smoking and the risk of developing tuberculosis. ${ }^{24,25}$

In the present study, community-acquired pneumonia (bacterial) was diagnosed as a cause of haemoptysis in 8.26\%. Different studies from India have shown that haemoptysis due to community acquired pneumonia to be ranging from $1.7 \%$ to $25.5 \% .10-12$

Among grading of severity, most of the patients presented with scanty haemoptysis ( $<30 \mathrm{~mL}$ ) $34.25 \%$ with pulmonary tuberculosis and its sequel being the predominant cause $(43.67 \%)$ combining them. The incidence of severe, massive and life-threatening haemoptysis were relatively low $8.26 \%$, $5.11 \%$ and $1.18 \%$ respectively with lung carcinoma being the predominant cause among them. Massive haemoptysis comprise of $5 \%-23 \%$ of all haemoptysis in most series $5,26,27$ and their mortality rate ranges from $23 \%-75 \% .5,27$

Chest $\mathrm{x}$-ray, chest computed tomography scan (CT scan) and bronchoscopy are the basic diagnostic tests in finding the aetiology of haemoptysis.7,9,28,29 Chest $\mathrm{x}$-ray is economical and should be done in all patients, as it provides basic diagnostic clue in most of the patients. However, some patients remaining undiagnosed need computed tomography scan (CT scan) thorax for better diagnostic accuracy and this combined with bronchoscopy not only adds in providing vital information but also best diagnostic results. Many recent studies on the diagnostic usefulness of diagnostic tests suggest the performance of chest x-ray and chest computed tomography (CT) scan in almost all patients with haemoptysis and bronchoscopy if risk factors are suggestive for lung malignancy, as for example smoking history.7,29

Sputum for acid fast bacilli smear/ GeneXpert and sputum for malignant cytology are simple and economical test with fair outcome and is advisable in suspected patients as done in our study.

Computed tomography scan thorax could not be performed in all patients $(79.13 \%)$ due to financial constraints, but it had a better positive outcome of $80.59 \%$ as compared to chest x-ray (55.11\%) and bronchoscopy (54.96\%). In fact combined use of computed tomography scan thorax (CT scan) with bronchoscopy provides better diagnostic yield than either diagnostic methods alone.

According to the experience of many authors,5,8 majority of haemoptysis can be controlled through conservative measures. This stands true in our study, also with $92.3 \%$ success rate.

Mortality in our patients was similar as compared to other studies from India, which ranges from $8.2 \%$ to $18.8 \% .^{30,12}$ Bronchial artery embolisation is a very effective procedure for controlling ongoing bleeding not controlled by conservative means. This is a shortcoming in our study, as we could not offer this procedure to our patients due to lack of this facility in our institutes. Patients needing this procedure were referred to another centre.

\section{CONCLUSION}

Most common cause of haemoptysis in our region appears to be tuberculosis, both active and its sequel followed by lung malignancy. Active case finding, and its appropriate management is needed that can reduce the incidence of haemoptysis. Besides this, proper awareness among masses about smoking prevention is also important. Computed 
tomography (CT) scan and bronchoscopy are important tool in the identification of the aetiology of haemoptysis. Most of the cases can be managed conservatively; however, some cases may need either bronchial artery embolisation, surgical treatment or bronchoscopic control of bleeding.

\section{REFERENCES}

[1] Cahill BC, Ingbar DH. Massive hemoptysis. Assessment and management. Clin Chest Med 1994;15(1):147-67.

[2] Reechaipichitkul W, Latong S. Etiology and treatment outcomes of massive hemoptysis. Southeast Asian J Trop Med Public Health 2005;36(2):474-80.

[3] Unsal E, Köksal D, Cimen F, et al. Analysis of patients with hemoptysis in a reference hospital for chest diseases. Tuberk Toraks 2006;54(1):34-42.

[4] Wong CM, Lim KH, Liam CK. The causes of hemoptysis in malaysian patients aged over 60 and the diagnostic yield of different investigations. Respirology 2003;8(1):65-8.

[5] Prasad R, Garg R, Singhal S, et al. Lessons from patients with hemoptysis attending a chest clinic in India. Ann Thorac Med 2009;4(1):10-2.

[6] Porzezinska M, Gorzewska A, Drozdowski J, et al. Assessment of hemoptysis etiology among patients hospitalized in pneumonology department of medical university of Gdansk in the years 1998-2002. Pol Arch Med Wewn 2005;114(1):658-63.

[7] Tsoumakidou M, Chrysofakis G, Tsiligianni I, et al. A prospective analysis of 184 hemoptysis cases: diagnostic impact of chest X-ray, computed tomography, bronchoscopy. Respiration 2006;73(6):808-14.

[8] Takahashi N, Akusawa H, Kisohara A, et al. A clinical review of hemoptysis. Journal of the Japan BronchoEsophagological Society 1999;50:391-5.

[9] Allewelt $M$, Lode $H$. Diagnosis of haemoptoe/haemoptysis. Dtsch Med Wochenschr 2005;130(9):450-2.

[10] Andersen PE. Imaging and interventional radiological treatment of hemoptysis. Acta Radiol 2006;47(8):78092.

[11] Talwar D, Chudiwal J, Jain R, et al. Massive hemoptysis in a respiratory ICU: causes, interventions and outcomes-Indian study. Crit Care 2012;16(Suppl 1):81.

[12] Nawal SK, Heda MR. Hemoptysis: a prospective analysis of 110 cases. Asian J Biomed Pharm Sci 2013;3:1-3.

[13] Singh SK, Tiwari KK. Etiology of hemoptysis: a retrospective study from a tertiary care hospital from northern Madhya Pradesh, India. Indian J Tuberc 2016;63(1):44-7.
[14] Santiago S, Tobias J, Williams AJ. A reappraisal of the causes of hemoptysis. Arch Intern Med 1991;151(12):2449-51.

[15] Pursel SE, Lindskog GE. Hemoptysis. A clinical evaluation of 105 patients examined consecutively on a thoracic surgical service. Am Rev Respir Dis 1961;84:329-36.

[16] van Kralingen KW, van Kralingen-Heijboer AC, Zimmerman $\mathrm{M}$, et al. Management of hemoptysis in a third world city hospital: a retrospective study. Tuber Lung Dis 1995;76(4):344-8.

[17] Souders CR, Smith AT. The clinical significance of hemoptysis. N Engl J Med 1952;247(21):790-3.

[18] Moersch HJ. Clinical significance of hemoptysis. J Am Med Assoc 1952;148(17):1461-5.

[19] Suri JC, Goel A, Singla R. Cryptogenic hemoptysis: role of fiberoptic bronchoscopy. Indian J Chest Dis Allied Sci 1990;32(3):149-52.

[20] Jindal SK, Gilhotra R, Behera D. Fiberoptic bronchoendoscopic examination in patients with haemoptysis and normal chest roentgenogram. J Assoc Physicians India 1990;38(8):548-9.

[21] Sharma SK, Dey AB, Pande JN, et al. Fiberoptic bronchoscopy in patients with haemoptysis and normal chest roentgenograms. Indian J Chest Dis Allied Sci 1991;33:15-8.

[22] Molinié F, Velten M, Remontet L, et al. The progression of lung cancer incidence in France (1978-2000). Rev Mal Respir 2006;23(2 Pt 1):127-34.

[23] Wahbah M, Boroumand N, Castro C. Changing trends in the distribution of the histologic types of lung cancer: a review of 4,439 cases. Ann Diagn Pathol 2007;11(2):89-96.

[24] Kolappan C, Gopi PG. Tobacco smoke and pulmonary tuberculosis. Thorax 2002;57(11):964-6.

[25] Bates MN, Khalakdina A, Pai M, et al. Risk of tuberculosis from exposure to tobacco smoke: a systematic review and meta-analysis. Arch Intern Med 2007;167(4):335-42.

[26] Hirshberg B, Biran I, Glazer M, et al. Hemoptysis: etiology, evaluation, and outcome in a terciary referral hospital. Chest 1997;112(2):440-4.

[27] Jean-Baptiste E. Clinical assessment and management of massive hemoptysis. Crit Care Med 2000;28(5):1642-7.

[28] Thirumaran M, Sundar R, Sutcliffe IM, et al. Is investigation of patients with haemoptysis and normal chest radiograph justified? Thorax 2009;64(10):854-6.

[29] Laurent F, Martins M, Sauty A. Hemoptysis: methods of localization. Rev Med Suisse 2005;1(41):2659-63.

[30] Rao PU. Hemoptysis as a symptom in a chest clinic. Indian J Chest Dis 1960;2:219. 